\title{
PASSING DOWN CULTURAL DESIGN HERITAGE THROUGH CRAFT OBJECTS OF MEMOIR
}

\author{
ว॰ส \\ KÜLTÜREL TASARIM MİRASININ \\ ZANAAT NESNELERIYLE GELECEĞE AKTARILMASI
}

Rezzan HASOGLU* - Selçuk ARTUT**

\begin{abstract}
$\underline{\text { Abstract }}$
Passing a skill (technē) learned from a master is carried across generations; therefore, a crafted object would also be considered a transitive element of a cultural heritance. Like the praxis of technology, skill is not an innate phenomenon but instead something artificial, made by humans. Crafted objects leave their marks in history by transferring tangible records of cultural heritage to the future, carrying traces of civilization of the period in which they exist. Investigating objects, which are produced in these terms as art and design objects within the diverse socio-cultural dimension, would take a critical place in clarifying many contemporary fundamental views. This article explores the meaning and the process of design, artisanship and cultural influences on these concepts through reciting the story of Çeşm-i Bülbül glass, which has been a significant object at the Ottoman banquets. Using this design object as an example, the article questions the meaning of design and the transformation process of 'becoming a meaningful object' through references from Heidegger's 'The Question Concerning Technology' and Borgmann's article 'Focal Things and Practices'.
\end{abstract}

Keywords: Cultural Heritage, Technology, Objects of Craft, Glass Design, Technē,

\section{$\underline{\mathbf{O}_{\mathbf{z}}}$}

Bir ustadan öğrenilen beceri (teknik) nesiller boyunca taşınırken aynı zamanda ortaya çıkan nesneler de kültürel mirasın zamanı yansıtan bir unsuru olarak tarihte yer alırlar. Teknolojinin uygulamalarında olduğu gibi, beceri de doğuştan gelen bir fenomen değildir ve insan tarafından sonradan ortaya çıkarılan bir olgudur. Tasarlanmış nesneler, kültürel mirasın somut kayıtlarını geleceğe taşıyarak ve içinde bulundukları dönemin uygarlık izlerini yansıtarak tarihe damgalarını vurmaktadırlar. Farklı sosyo-kültürel boyutlarda üretilen sanat ve tasarım nesnelerinin araştırılması, günümüzdeki birçok tartışmanın aydınlatılmasında kritik bir yer tutmaktadır. Bu makale, Osmanlı yemeklerinde önemli bir yer tutan Çeşm-i Bülbül camının öyküsünü anlatarak, bu kavramlar üzerinde

* MA., Studio Sahil, London / United Kingdom. • E-mail: rhasoglu@gmail.com

** Dr. Öğr. Üy., Sabancı University, Faculty of Arts and Social Sciences, Visual Arts and Visual Communication Design, Istanbul / Turkey.

ORCID ID: 0000-0001-7323-7234 • E-mail: sartut@sabanciuniv.edu 
tasarım, zanaatkarlık ve kültürel etkilerin anlamını ve sürecini araştırmaktadır. Tasarım nesnesini bir örnek olarak ele almakta ve Heidegger' in 'Teknolojiye Dair Sorgulama' ve Borgmann'ın “Odak Nesneler ve Uygulamaları” başlıklı makaleleriyle, tasarımın anlamını ve "anlamlı bir nesne olma" dönüşüm sürecini sorgulamaktadır.

Anahtar Kelimeler: Kültürel Miras, Teknoloji, Zanaat Objeleri, Cam Tasarımı, Teknik,

\section{INTRODUCTION}

The definition of cultural heritage framed by UNESCO implies that traditions and customs are a part of this heritage. "Cultural heritage is the legacy of physical artifacts and intangible attributes of a group or society that are inherited from past generations, maintained in the present and bestowed for the benefit of future generations." While an archeological site from the Byzantine Empire is considered cultural heritage, handcrafted objects are also included to this definition. According to UNESCO, the knowledge and skills to produce traditional crafts are considered as "intangible cultural heritage" based on the following criteria: the specific period, inclusiveness, the way culture is represented, and communal aspects. ${ }^{2}$

In order to transform a natural resource (wood, metal or glass) into a finished object, which is considered artificial, a systematic and repetitive training of a craftsperson is essential. Skill (technē) is required for training, and humans define the skillset for the execution of an object. The improvement of technology is proportional to the advancement of skill. As the skill improves, craftspeople develop new tools and techniques to find novel approaches to the same goal. Additionally, as the development of cultural heritage involves the use of technology, the transition of cultural artifacts has progressed over time in parallel to the progress of technical knowledge. Sennett expresses the critical influence of hands-on learning in gaining technical knowledge. ${ }^{3}$ According to Sennett, "The craftsman represents the special human condition of being engaged." ${ }^{\prime 4}$ The craftsman who repetitively applies his skills to produce the craft-object perfects his skills and goes through an embodied experience. In order to understand this embodied experience, consider the example of a person applying chalk onto a blackboard. An engaged subject initiates an embodied experience when they apply chalk to a blackboard. ${ }^{5}$ During the incorporation of the chalk material and the surface of the blackboard, the subject becomes aware of the activity of applying chalk on the blackboard. As a result, the chalk becomes an extension of the body and the blackboard reveals all its properties to the subject. Therefore, the

1 UNESCO. (n.d.). Retrieved from http://www.unesco.org/

2 Kurin, 2004, 66.

3 Sennett, 2008, 145.

4 Sennett, 2008, 158.

5 Ihde, 1979, 7. 
embodiment experience is a way of experiencing the self at work. Similarly, crafting an object by hand arouses an experience of embodiment with the material, and the unison of human experience with material compatibility reveals multifarious forms of expressions.

During the process of handcrafting, the immersed focus on engagement with the work itself creates a sense of curiosity and evokes diverse critical thinking methods for the craftsperson. For instance, the art of glassblowing requires years of practice solely with hot glass material. The gaffer, a person who blows the glass, must follow a certain hierarchical system to learn and master the necessary skills to refine the art of glass making. Consequently, a person evolves into being a competent craftsman through attaining several codes of sophisticated experiences. Hence for a craftsman, conceiving a product rarely blossoms from an ambiguous thought but rather from intuitive exploration. As Nimkulrat asserts, "Craft is thus - a means for logically thinking through [the] senses." ${ }^{\prime 6}$ While the limits of our senses expand in the light of technological advancements, humans become perceptive to seeing and hearing what they are not normally capable of. However, technological apparatuses, which provide an experience between the object and a human, weaken the feeling of a first-hand understanding by dividing the approximation into diverse layers. Consequently, during design processes computer aided digital design environments are eliminating the interaction occurring during an experimentation process of an object.

In the process of crafting through experiencing the crafted material, a craftsman has to think intuitively about the object at hand, the order of operation, and the object's purpose. A gaffer who gathers the glass from the furnace uses a ladle or a folded piece of newspaper to shape hot glass. The subject has to intuitively consider the material properties and the order of operations in forming the glass on the hot pipe. The train of thought of the gaffer reveals the essence of the glasswork that is being formed. The methodology of the craft transforms "the unknown to the known," bringing to the fore Heidegger's understanding of technology as a way of revealing. When a material reveals itself in a form, the process of revealing embraces activities and the material preferences of the craftsmanship involved. ${ }^{7}$ A gaffer who uses hot glass would know how and when to disconnect the glass piece from the pipe. There is little margin for error in the process of glassmaking, and once made a vessel can rarely be corrected. ${ }^{8}$ The possibility for error opens the space for further perfection and the possibility of new embodied experiences.

The maker is only concerned with the excellence of the work, as "Designers need not allow their activity to be appropriated by social activist[s] or even worse, by consumers." However the definition of "cultural heritage" requires an appeal to the

\footnotetext{
6 Nimkulrat 2012, 7.

7 Heidegger, 1977, 152-153.

8 Küçükerman, 1985, 14.

9 Wang, 2013, 4-15.
} 
public understanding of aesthetics. There is a gap between the individual labor of the craftsperson aiming for an excellent craft-object and the public's demand and desire to consume the craft-object in the form of a finished product. The concern of the maker for excellence makes the quality of work impersonal. While the high-quality work creates an inner-satisfaction for the maker, the margin of error contradicts the personal connection to the work..$^{10}$ Although the craftsperson's relationship to the work is impersonal, this contradiction enables skill to be passed down so that standards of quality remain intact for other generations. During the Industrial Revolution, a craftsperson would compete with a machine to achieve comparable results. Yet the maker has to become a machine, an impossible task, to win the competition. Thus, craftsmen cannot fit modern-machine powered technology. ${ }^{11}$ The craftsperson's process of making deviates from a machinepowered manufacturing by the imperfections in the craft-object. In a glass object, intricate details such as unequal wall thickness or asymmetrical patterns reveal the glassmaker's human-ness. While aiming for the excellence within the work, these imperfections reveal the process of developing skills which are passed down to other people.

In this paper, the question, "How is cultural heritage passed down through objects of craft?" will be evaluated by expanding the terms mentioned above and focusing on a specific example of history and making of Çeşm-i Bülbül glass. An Ottoman-Turkish cultural object, Çeşm-i Bülbül glass is a handmade product sold in Paşabahçe retail stores and which belongs to the one of the largest glass manufacturers in the globe, Şişecam A.Ş.

\section{CRAFT OBJECTS OF MEMOIR}

Craftsmanship is a projection of human knowledge of material, aesthetics, and the function of an object for a certain purpose. A craftsman focuses and applies necessary knowledge to create an object. This focal practice calls forth exertion, skill, self-transcendence, perseverance, endurance, patience, commitment and attention qualities that device enhanced leisure tends to undermine or dissipate. ${ }^{12}$ As a result, the object represents the imagination and the knowledge of the craftsman. When the object is passed down to the next generation, all annotations that the object carries within are also transferred. However, for a new artisan possessor to unravel these annotations, he or she should also hold the knowledge necessary to make the artifact. During the engagement process in focal things, participants would observe alternating options beyond their intended self-focuses. This focal engagement guides them to reveal the hidden by creating a dialectic discourse. Even though one wants to share this discovery of orienting the power of a focal thing, the experience is individualistic: one cannot force others to recognize focal objects. Focal objects make possible the assessment of technology. Focal objects also help people see new perspectives on life, which contribute to individuals and cultures within the technological world. Otherwise, without the experience of focal

10 Sennett, 2008, 27.

11 Heidegger, 1977, 48.

12 Heikkerö, 2005, 253. 
objects and practices, the subject cannot appreciate this experience of knowledge. The focal practice will be detached from its cultural significance and it will not be carried on. Thus, focal objects provide "a meta-technological viewpoint"13 that enables us to weigh technological devices. ${ }^{14}$ Without the focal objects, or crafted objects, we will not be able to gauge the weight of technological advancements. In that respect artisans have a crucial role in exploring the obscure properties of subjects in disguise with hands on practical experience to contribute a direction for technological advancements.

\section{PASSING DOWN CULTURAL HERITAGE / TRANSITION / TRANSFORMATION}

Museums are significant examples of the conservation of cultural heritage. In an organized and systemized point of view, museums present elements of cultural heritage intact. Many craft objects and artifacts are conserved and displayed in these controlled environments. Craft objects such as cabinets, tables, and Crystal glass displayed within museums such as Art Institute of Chicago, Musée d'Orsay and Rijksmuseum, are categorized under "Decorative Arts." These objects would have life spans over a hundred years old. Even though these objects belong to a cultural heritage, museums do not consider them as "design objects." In contrast to these collections, the Design Museum Helsinki, the Design Museum Copenhagen and MoMA host "design" objects which are also handcrafted. For example, glass objects by Timo Sarpaneva are displayed in a protected housing within the Design Museum Helsinki. While hand crafted glassware is on display within the museum, mass-produced versions of the same object are available for the sales market. The glassware is also a part of today's collections of Iittala glass (one of the largest tableware glass manufacturers in the world) and Rosenthal ceramics collections. ${ }^{15}$ The example above shows that museums have a mission of sustaining design culture by displaying contemporary craft objects categorized under "design objects" in their collections. A craft object in a prestigious design museum collection legitimizes the exertion of preserving intangible cultural heritage by its presence and its relation to the history.

The vagueness of clarity between the definition of "decorative object" and "design object" is a critical issue for cultural heritage. The production purpose of decorative objects is to present visual aesthetic content in a place where objects stand individually or as collectives with other neighboring objects. Yet, design objects exhibit a different stance when a detachment of effort from its historical mission problematizes its decorative definition. Design objects are objects which host a functionality characteristic to rational criteria as well as aesthetic approaches that exist within their structure. Considering objects in these terms, we see that the two definitions intersect at many points. In contrast to design objects, decorative objects exhibit a more passive stance by

13 Borgmann, 1984.

14 Heikkerö, 2005, 253-254.

15 Aav \& Brännback \& Viljanen, 2006. 
withholding their functionality. In an analysis of an object's manufacturing techniques, in which an object is constructed without the fore-mentioned distinction, to the analysis of displayed objects within museums, many definitive points are excluded from debates regarding the understanding of cultural heritage. If our world is built upon a rational value structure, demonstrated especially through the evaluation of objects produced in a recent period, the design properties are more prominent than the decorative properties of these types of objects. As Wang asserts, truth derives from reason. Reason is an extension of imagination. Design originates from the imagination and shapes reason into a visual and a functional object. ${ }^{16}$ There is a contrast between techne (knowing by making) and epistēme (knowing by thinking). While techne is limited to sensation, memory and imagination, epistēme can know necessary reality because it is only limited by the universal and eternal rules of logic. Design combines both technē and epistèmē. Without only making things by hand through focal practice, design calls forth reason through proactive, logical thinking which determines solutions and through evaluating various circumstances for the future. A designer or a maker has to acknowledge the consequences of a design object's impact on its users. Users are members of a culture to which they also contribute. Design provides the object material for cultural heritage. Since the reason (logos) reveals necessary, universal truths, design is a method of transforming cultural heritage into a universal truth. ${ }^{17}$

It is necessary for culture to be passed down through crafted objects of memoir because these objects are imagined (which reveals the true reason behind it) and crafted through focal practices. The objects of memoir are the vessels that carry the past (cultural heritage) to the future (necessary and eternal truths of existence). But objects of memoir also evolve along a different path because culture belongs to the past with its connotation of inheritance. However, imagination for design aims to move the cultural heritage into the future. This would only be possible if the skills and knowledge in the making of a design object is passed down through craft objects of memoir.

\section{HISTORY OF ÇEŞM-İ BÜLBÜL, A DESIGN OBJECT OF CULTURAL HERITAGE IN TURKEY}

The history and the progression of glassmaking, especially the Çeşm-i Bülbül glassware from Turkey, illustrates the idea of "passing down of cultural knowledge through objects of craft." Glass is a wide spread material and object in the world. Silica (the chemical compound $\mathrm{SiO}_{2}$ ) is a common fundamental constituent of glass. The quality and properties of glass vary depending on the material's chemical combinations. The raw chemicals which form glass can be easily found, making glass one of the cheapest materials for mass-manufacture. However, the craftsmanship and design of a glass object is what makes the object valuable. The knowledge through the process of making, or the technique, determines the object's value.

16 Wang, 2013, 5-6.

17 Flusser, 1999; Wang, 2013. 
Fig. 1:

Possession of glass-makers blowing glass while passing in from of the Sultan. $16^{\text {th }}$ Century

Turkish Miniature "Surname- $i$

Hümayun" No. 4/1344 Fol. 32b (Topkapi Palace Museum). (Bayramoğlu, 1976, 119.)

Glass has been used widely throughout the world from the earliest periods of time. In the Ottoman Empire during the Beyazid III reign, the glass industry began to grow. Glass-guilds would hire apprentices and train them to higher ranks of skill before they would enter the market. In 1582, Murad III threw a party for the circumcision of his son Şehzade Mehmed (III). This is recorded historically within the miniature book titled, Surname-i Hümayün, which contains many scenes from the event. In six miniatures, glassmakers from the Camgeran Guild gaff and carry glass objects on carriages or by foot. From the book's miniature drawings, it can be understood that glassmaking held an important place in the Ottoman Empire and that people regarded it as a high craft. ${ }^{18}$ (See Fig. 1 and 2) The Palace was supporting glassmakers: providing them the silica, wood to burn their kiln and furnaces, making quality control for the products, choosing the fine craftsmen to Enderun- $i$ Humayun (a privileged school for the Palace members) where academicians supervise artisans and fine artisans are paid in tri-month salaries. ${ }^{19}$
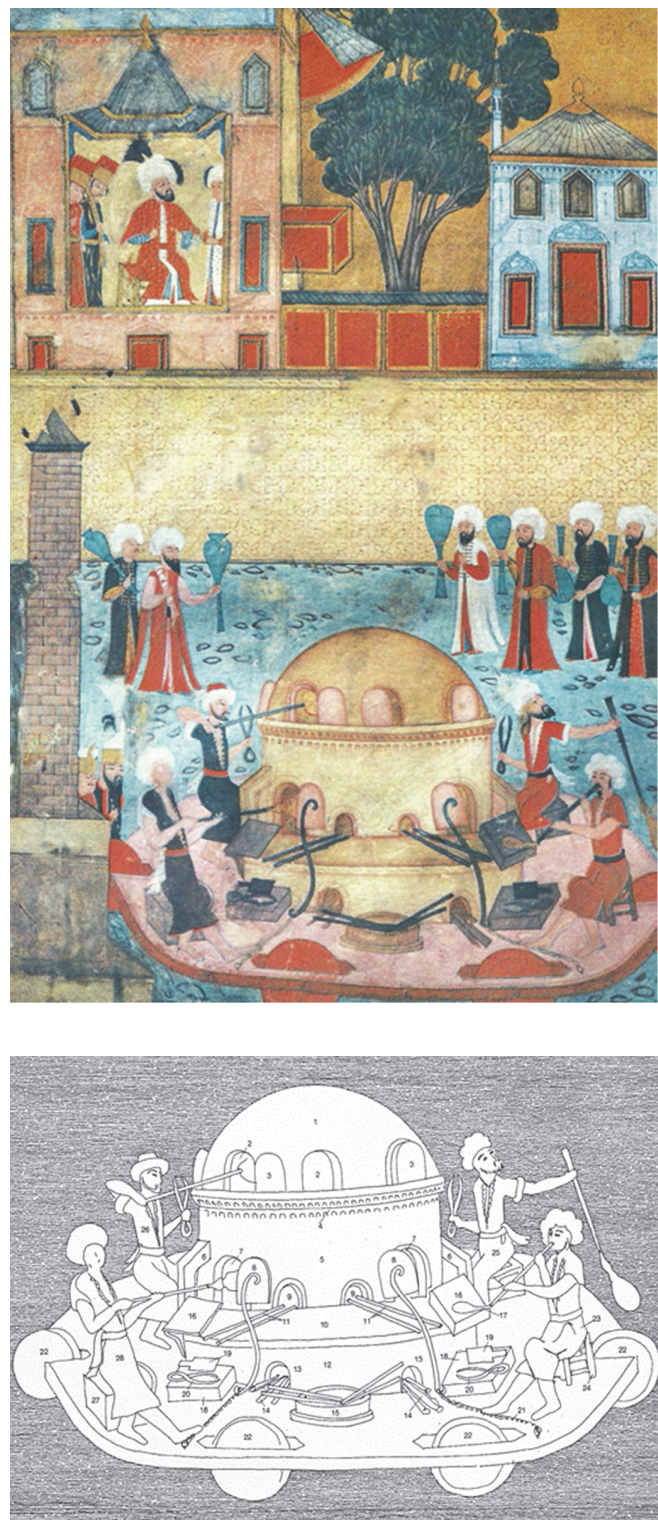

Fig. 2: Diagram showing in detail the tods and implements in the workshop. (Küçükerman, 1985, 151)

18 Bayramoğlu, 1976; Küçükerman, 1985.

19 Küçükerman, 1985, 153. 
The glass industry developed the most at glass center situated between Egrikapi and the Tekfur Palace in the Ottoman Empire during the $17^{\text {th }}$ and $18^{\text {th }}$ centuries. ${ }^{20}$ Other glass factories open in various locations within Istanbul. The raw material came from an approximate distance from the city. Sultan Mustafa III created a foundation at Tekfur Palace at Edirnekap1 in Istanbul for craftsmen and workers which protected the craftsmen's legacy, standards of production, and which would provide financial support for craftsmen in the event of injury. This large investment was made during the beginning of the Industrial Revolution in Europe. In a time where competition shifts from handproduction to machine-powered production, the Ottoman Empire began to struggle with economic problems. In the following years the foundation at Tekfur Palace could not compete with European glass-production. Until 1716, the Ottoman Empire gave permission to the import of glass from Europe. By the decision of the royal edict, the import of the Venetian glass was restricted, and the import of Bohemian glass became a preference for import. ${ }^{21}$

During his reign, Sultan Selim III (1789 - 1808) sent Mehmed Dede to Venice to be trained in the practice of reticello glass. Upon his return, as a document states, "Mehmed Dede, a member of the order of Whirling Dervishes founded by Mevlana Jelaluddin-i Rumî, manufactured glass-ware in a work-shop he opened in this country. He had learned this skill in Italy, and manufactured gilt crystal bowls, large dishes, water glasses and decanters. Such glass-ware was

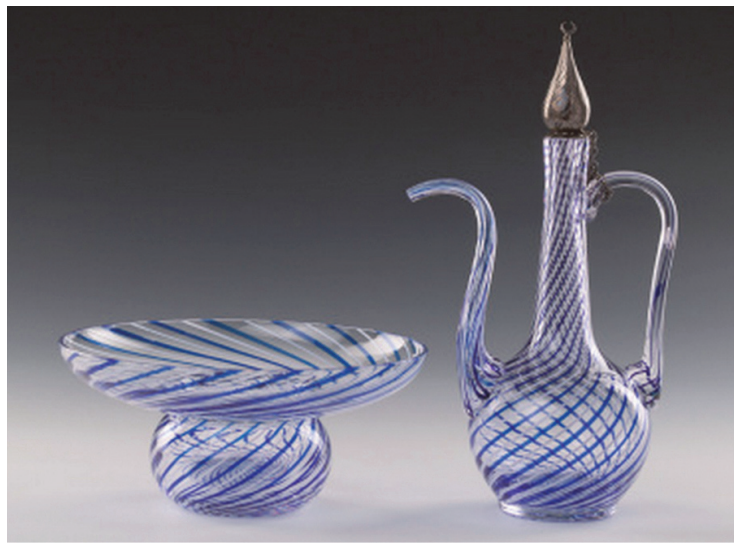

Fig. 3: Çeşm-i Bülbül vessels. called Beykoz-ware." The most famous type of glass manufactured there was Çeşm-i Bülbül (see Fig. 3), a very fine glass striped and moiré. Çeşm-i Bülbül and Beykoz-ware are the two distinct styles of what is called "verre turc" (Turkish glass). ${ }^{22}$

The name Çeşm-i Bülbül means "eye of a nightingale." The first workshop was opened in Çubuklu and then at Beykoz during the Reign of Sultan Abdulmecid (18391861). Tahir Efendi was appointed director of this workshop. ${ }^{23}$ Tahir Efendi was also the

20 Küçükerman, 1985, 147.

21 Küçükerman, 1985, 154.

22 Bayramoğlu, 1976; Bengisu, 2013.

23 Bayramoğlu, 1976, 60. 
Master of the Imperial Mint and he presented samples of the glassware about a year later to the Sultan. The Sultan ordered that the presented objects from the factory should be sent with a note to the Grand Vizier, who in turn, should forward them on behalf of the Sultan to the Sheikhulislam and to his various Ministers. ${ }^{24}$ Later correspondence followed between the subjects, in which each thank each other for this "precious crystal-glass."

Crystal glass is made with a mixture of lead with the chemical components of a regular glass and it reflects the light better than the regular glass. These reflective properties make the object more precious. The last glass factory that opened in Ottoman history was in 1899 by Saul Modiano, an Italian Jewish craftsman. The factory in Pasabahce held 500 workers and left the style A la Turca as a heritage before it closed in $1902 .{ }^{25}$

Despite the brief history of Ottoman Glass, glass objects held a prominent place in history and were valuable objects of craft. In social terms, there was support between the glassmakers and the government for working conditions to facilitate the creation of the best work. Glass craft was recorded in the royal history books and was presented as giftware to important politicians. ${ }^{26}$ Sakaoğlu and Akbayar also verify that the Beykozware and Çeşm-i Bülbül are cultural heritage:

\begin{abstract}
"On the other hand, import and sale for a lower price of Venice-made replicas of Cesm-i Bülbüls, which cannot be easily distinguished from the local versions, caused local ones to be produced less and sold in an antique's price. For this reason, Ottoman Çeşm-i Bülbüls also gained qualification as a symbol for a family's wealth and good manners as an object: Not only in the Istanbul and its surroundings but also it found market in Europe, in the Middle East, especially in Iran."
\end{abstract}

During the 1900s and 1920s, the Ottoman Empire and later, the Republic of Turkey struggled the First World War, the Independence War, and all the economic and sociological issues that came with these wars. In 1933 Y. Ziya Üçüncü built the first private factory to manufacture glasses for water in the neighborhood of the Tekfur Palace at Edirnekapi. ${ }^{27}$

Additionally, the first five years of the 1933 industrial plan of the Republic of Turkey suggest the establishment of a glass industry. For the legislation of an industry law, the 1933 Ministry of the Economy of Turkey states, "We cannot continue to allow the importation of products of everyday use such as bowls, plates, and porcelain, and glassware, particularly when we observe that other manufactures requiring more complicated technical knowledge are well advanced in our country." 28 This statement

24 Bayramoğlu, 1976, 61.

25 Sakaoğlu and Akbayar, 2000, 69.

26 Sakaoğlu and Akbayar, 2000, 69.

27 Bayramoğlu, 1976, 83.

28 Bayramoğlu, 1976, 84. 
shows that the glass industry was re-initiated because of a basic necessity to create domestic industry, but the technology remains dependent on technical knowledge.

In 1934, Turkish Bank (İş Bankası) became responsible for the establishment of a glass factory in Paşabahçe near Beykoz. A French company named Stein administered the factory for the first two years before Turkish Glassworks Inc. took command. At the beginning there were only two furnaces in the factory, one of which came from the Modiano factory. This transition shows that technical knowledge was passed down in other aspects, such as choosing matching factory location and re-using past machines. Like the Ottoman History of glass, the Turkish glass industry followed a similar strategy by opening the first industrial glass factory at Tekfur Palace, stopping the import of glass to the country and shifting the artisanal glass production to Pasabahce.

In order to mass-produce an object of craft, a heritage of technical knowledge came in hand to for the growth of the glass industry in Turkey. During and after the Second World War, the factories were established and continued manufacturing in different cities. In the meantime, Çeşm-i Bülbül became popular again as a giftware for upper and middleclass families. Like the Ottoman era, glass represented the wealth and good manners of a family. Those who inherited original Çeşm-i Bülbül glasses from their grandparents were considered to come from the rooted families of the county. Those who could afford to buy glass were families progressing into a higher social status. In the late 1990s and onwards Paşabahçe Glass Company, a sub group of the Turkish Bank İş Bankası, started to design and make new hand blown Çeşm-i Bülbül glassware. The company also made documentaries on the artisanship of these products. In the present day, not much has changed since the nineteenth century. Çeşm-i Bülbül is still an object of high craft and considered as a valuable giftware and family heritage. Mehmet Dede's creation has turned into a tradition and has become a cultural heritage. ${ }^{29}$ The Turkish market grew quickly in mid $20^{\text {th }}$ Century and began exporting its products to other countries. The learned Venetian technique to make Çeşm-i Bülbül was imitated in Venice under the name verre turc (Turkish glass)..$^{30}$

In the present day, Pasabahce is leading the glass industry and design in Turkey and on the international scale. In 2014, for the $2^{\text {nd }}$ Istanbul Design Biennial, the company collaborated with international designers and makers. ${ }^{31}$ The multi-cultural collaboration of designer and makers exploring new material properties and production techniques, received world-wide attention from the media and professionals. The cultural heritage of Turkish glass continues to evolve from the traditional style into a new form and function language via collaborations with makers and designers.

29 Bayramoğlu, 1976, 98.

30 Bayramoğlu, 1976, 98.

31 http://www.glassistomorrow.eu/ 


\section{MANIPULATION OF THE CULTURAL HERITAGE}

Following Sennett in the transfer of knowledge and skill from the master to artisan, an artisan imitates his master's work before becoming a journeyman. An apprentice must perfect his skills through imitation. Once this task is completed, he must then find novel approaches to attain the same quality of craft. During this learning process, apprentices' experiment with tools and materials to find novel approaches. Within these experimentations there are sometimes accidents which lead to the discovery of new techniques. These "happy accidents," or moments of "dialectic creativity," create new techniques from old techniques.

Dialectic creativity, depending on the purpose of the artisan, can augment the value of the object in its design language and intellectual approach. However, it can also lead to new ways of imitating the object through the manipulation of the production processes and materials. Artisans, who imitate not only their masters' work but also other designers' works, create alterations in the cultural heritage. The imitation of a master's work has a purpose of "learning through making," but the imitation of a design object would have ethical issues of intellectual property which distinguish the imitated object's social impact. This social impact affects the object's cultural heritage. As more imitated objects are made by artisans, there are fewer original contributions to cultural heritage. Dorrestjin and Verbeek state:

"Applying nudges in design is a delicate affair, since it inevitably involves interference in people's behavior. Aware of the ethical issue that this could lead to manipulation and domination, Thaler and Sunstein (2008) define good nudges as choice advisors that should never be coercive." 32

In the present day, there are still many imitated objects. For instance, one lamp by Tom Dixon is down-copied (low-quality imitation) by a metal worker in Şişhane, Istanbul, then again down-copied in China, and again copied in Istanbul. ${ }^{33}$ In each step, the aim is to maintain design while reducing manufacturing cost. However, the cultural heritage and the technical knowledge in craft are different in each step as the design is incrementally altered to reduce the amount of material used. In the last step of copying, the design and the value (due to the material and craft) are very different from the original design object. In the steps of the reproduction of a designed object, the cultural heritage is also altered because the copy skews the imagination of the craftsman, and therefore the source of his reason, the truth. While it may seem immediately beneficial for the business owner, this process is harmful for long-term cultural heritage because the source of making does not originally belong to the person from that culture.

32 Dorrestjin, Verbeek, 2013, 47.

33 İngin, 2011. 


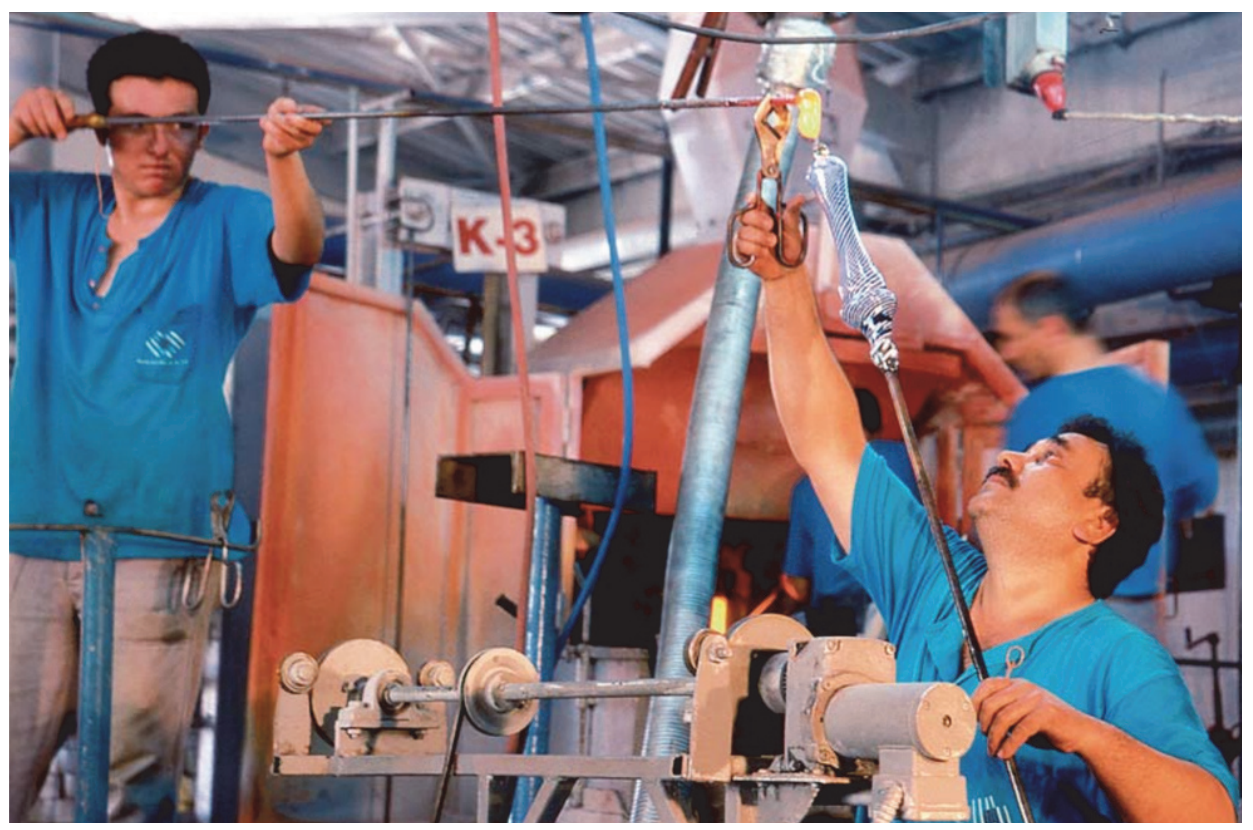

Fig. 4: Artisans producing a Çeşm-i Bülbül vessel.

In terms of production, the Çeşm-i Bülbül technique can only be made by hand. Imitation is only possible by hand. To make this glass, a gaffer must combine both white and blue colors within crystal glass. With each color, the gaffer first pulls glass rods, then cuts them into equal lengths, and finally aligns them into equal spacing and height. The colored rods are reheated before they are wrapped around the hot crystal glass, which is gathered from the furnace on a different blowpipe. After this step, depending on the gaffer's decision for the design, the glass is blown into a mold or shaped freely by hand before it is placed into the kiln to cool down incrementally. As described above, the process of making a Çeşm-i Bülbül vessel requires multiple steps of preparation and proactive thinking. Some steps, such as pulling and aligning colored rods, is only possible by a human. In addition, a machine of mass-production would not be able to contribute the same delicateness to the object. Glass machines are able to produce colored glass objects, but these machines cannot design custom colored glass patterns. A machine cannot imitate complex patterns, as an advanced gaffer would realize. (see Fig. 4)

\section{CONCLUSION}

Through exploring cultural heritage artifacts and investigating methods of passing it on to the other generations, this article will be an exploratory source to process based design studies. Designers would create more appropriate projects based on the cultural tendencies of the people. Manufacturing techniques of various artisans, which 


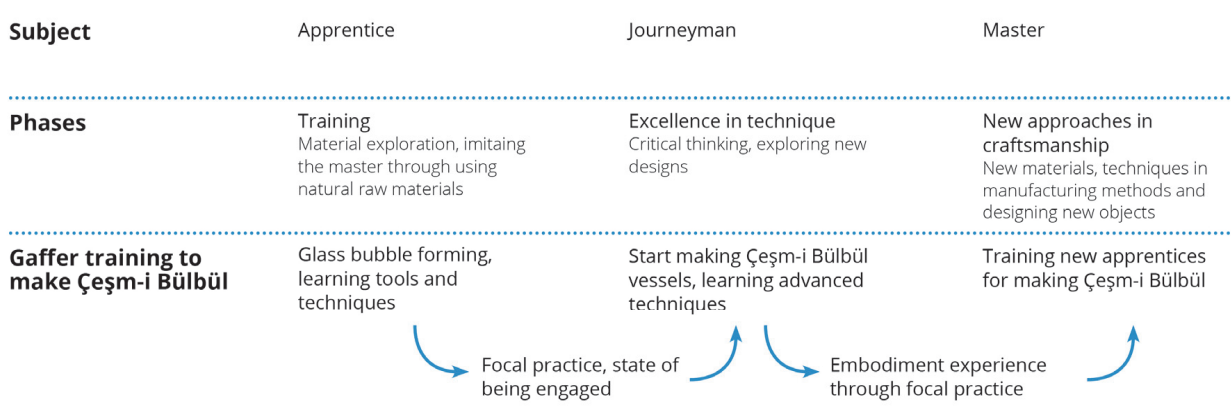

Schema of passing down intangible cultural heritage

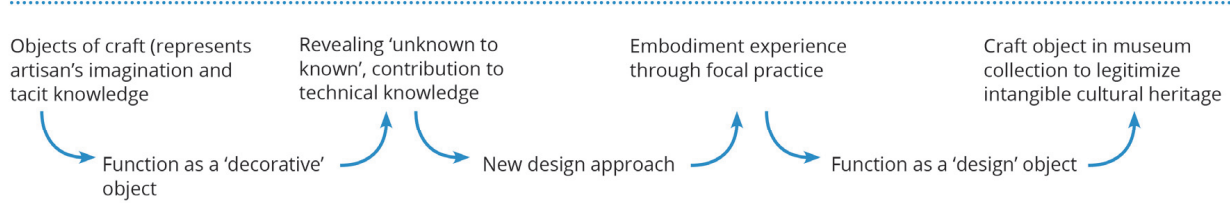

Table 1: Formation of objects of craft.

would also be considered as parts of the cultural heritage, enable designers to conceive multiple perspectives for accomplishing innovative projects.

Many experiences can be viewed or watched through the lens of technology. A person can learn how to knit by watching a YouTube channel. This visual sharing of knowledge is useful but remains incomplete. Without hands-on making, the experience stays as a mere reflection of the actual activity. Without testing a new knowledge, one cannot fully comprehend technique. The word "technique" (rooted from techne) itself conveys "learning by making."

Apprentice and master relation are part of the intangible cultural heritage because of the social and technical experience between the two subjects. Although an apprentice learns through imitation, after a certain amount of time and experience, he/she develops new approaches and new designs. On the contrary, a person who only observes to learn cannot fully comprehend the many façades of a skill. For glassblowing, one cannot learn how to make a simple glass bubble, much less a Çeşm-i Bülbül, without the experience of a glass shop. The student or apprentice must first learn to hold a blowpipe, check that it is not clogged, gather glass from the furnace, understand the working temperatures of the material, shape the glass into an elliptical sphere, and then create enough air pressure within the rotating blowpipe to create a bubble within the glass. Even this elementary glass form requires many steps that require hands-on experience. Knowledge transfer is only possible through making. 
In the relationship between humans and technology, the key point is awareness that technology is human-related and that it advances through knowledge transfer. New techniques lead to new inventions within technology. Through focal practices and embodiment, one can expand their own imagination and become aware of their surroundings in order to reveal necessary and universal truths. The history and the making of Çeşm-i Bülbül as a craft object of memoir illustrates how cultural design heritage is passed down through generations from masters to apprentices. Only one who knows the technique of making can understand the value of this craft object of design, accept it as a memoir in a family inheritance, and pass it along as cultural connotation and value. 


\section{BIBLIOGRAPHY}

Aav M. \& Brännback E. \& Viljanen E. (2006). Timo Sarpaneva Collection. Helsinki: Designmuseo.

Bayramoğlu F. (1976). Turkish Glass Art and Beykoz-ware. Istanbul: İstanbul Matbaas1.

Bengisu M. \& Bengisu F. E. (2013). Beykoz Glassware and the Elements that Shaped It in the Nineteenth Century. Design Issues. 29(1), 79-91.

Borgmann A. (1984). Technology and the character of contemporary life: a philosophical inquiry. Chicago: University of Chicago Press.

Doğan E. T. (2012). Reinterpreting the Craftsmanship Today: Is It New Craftsmanship? Journal of Labor Relations. 3(1), 67-85.

Dorrestjin S. \& Verbeek P. P. (2013). Technology, Wellbeing, and Freedom: The Legacy of Utopian Design. International Journal of Design. 7 (3), 45-56

Flusser V. (1999). The Shape of Things: A Philosophy of Design. London: Reaktion Books.

Glass is Tomorrow. (n.d.) Retrieved March 16, 2015, http://www.glassistomorrow.eu/

Heidegger, M. (1971). The origin of the work of art (242-79). na.

Heidegger, M. (1977). The Question Concerning Technology. New York: Harper and Row Publishers, Inc.

Heikkerö T. (2005). The Good life in a technological world: Focal things and Practices in the West and in Japan. Society. (27), 251-259.

Ihde, D. (1979). Embodiment Relations. In Technics and Praxis (6-11). Dordrecht: D. Reidel Publishing Company.

İngin A. K. (2011). Made in Şişhane. (1st ed.). İstanbul: Kingdom of Netherlands and Çelikdizayn.

Kurin, R. (2004). Safeguarding Intangible Cultural Heritage in the 2003 UNESCO Convention: a critical appraisal. Museum international, 56 (1-2), 66-77.

Küçükerman, Ö. (1985). The Art of Glass and Traditional Glassware. (1st ed.). Ankara: Türkiye İş Bankası Cultural Publications.

Nimkulrat, N. (2012). Hands on Intellect: Integrating Craft Practice into Design Research. International Journal of Design. 6(3), 1-14.

Sakaoğlu N. \& Akbayar N. (2000). Cam İşleri. Osmanlı'da Zanaatten Sanata Volume 2. (56-71), Istanbul: Körfezbank.

Sennett, R. (2008). The Craftsman. New Haven: Yale University Press.

Wang, J. (2013, Spring). The Importance of Aristotle to Design Thinking. Design Issues (29) $2,15$.

What is Intangible Cultural Heritage? UNESCO. (n.d.). Retrieved from www.unesco.org/ 
Ege Üniversitesi, Edebiyat Fakültesi

Sanat Tarihi Dergisi ISSN 1300-5707

Cilt: XXVII, Sayı: 2 Ekim 2018
Ege University, Faculty of Letters

Journal of Art History

e-ISSN 2636-8064

Volume: XXVII, Issue: 2 October 2018

Yavin Tarihi | Date of Publication

31.10 .2018

Internet Sayfası (Acık Erișim) | Internet Page (Open Access)

\section{DergiPark}

http://dergipark.gov.tr/std 